\title{
The effect of feed restriction on expression of hepatic lipogenic genes in broiler chickens and the function of SREBP 1 is
}

\author{
Pei H. Wang, Ya H. Ko, Hong J. Chin, Chichen Hsu, S.T. Ding *, Ching Y. Chen * \\ Department of Animal Science and Technology/Center for Biotechnology, National Taiwan University, Taipei 106, Taiwan
}

\section{A R T I C L E I N F O}

\section{Article history:}

Received 13 February 2009

Received in revised form 7 April 2009

Accepted 15 April 2009

Available online 19 April 2009

\section{Keywords:}

$\mathrm{ACC}_{\alpha}$

Chicken

Fast

Fatty acid synthase

SiRNA

SREBP1

\begin{abstract}
A B S T R A C T
To study the role of sterol regulatory element-binding proteins (SREBP) in lipogenesis and cholesterol synthesis in the chicken, two experiments were carried out. In the first study, seven-week-old broilers $(n=16)$ were allocated into 2 groups, fasted for $24 \mathrm{~h}$ or refed for $5 \mathrm{~h}$ after a $24 \mathrm{~h}$ fasting. The mRNA concentrations for SREBPs and other lipogenic genes in the liver were determined by quantitative real time PCR. The hepatic mRNA relative abundance of lipogenic genes and genes involved in cholesterol synthesis were significantly greater $(p<0.001)$ in the refed broilers. Similar results were demonstrated with Northern analysis. The data suggest that in the liver of fasted broilers, genes associated with lipogenesis and cholesterol biosynthesis were inhibited. Indeed, the mRNA concentrations for fatty acid synthase (FAS), malic enzyme, and stearoyl coenzyme A desaturase were almost undetectable after the $24 \mathrm{~h}$ fasting. The data also demonstrated that the expression of lipogenic genes coordinate well as a group during the refeeding period. Second, three small interfering RNA ( siRNA) oligonucleotides against SREBP1 were designed to be used in transfecting a chicken hepatocarcinoma cell line LMH. One of the three siRNAs effectively reduced SREBP1 mRNA concentration $(p<0.01)$. The acetyl coenzyme A carboxylase $e_{\alpha}\left(A_{C C}\right)$ mRNA was also significantly reduced by the SREBP1 siRNA treatment, suggesting that SREBP1 can upregulate the expression of this lipogenic gene. This siRNA, however, did not affect the mRNA for FAS. Taken together, the RNA interference study showed that SREBP1 has the ability to regulate the expression of $A_{C C}$. This study has helped us understand more about the function of SREBP1 and the physiology of the broiler chickens.
\end{abstract}

(c) 2009 Elsevier Inc. All rights reserved.

\section{Introduction}

In mammals, there are three sterol regulatory element-binding proteins (SREBP), SREBP1a, SREBP1c, and SREBP2. The SREBP1 and SREBP2 are transcribed from two different genes (Hua et al., 1993; Yokoyama et al., 1993) and SREBP1a and 1c are transcribed from the same gene, but controlled by different promoter sequences (Hua et al., 1995). The SREBP1a is a transcription factor that stimulates the expression of lipogenic and cholesterol biosynthesis genes containing a sterol regulatory element promoter region in mammals whereas SREBP1c works on lipogenic genes only (Shimano, 2001). These lipogenic genes include fatty acid synthase (FAS) and acetyl coenzyme $A$ carboxylase ${ }_{\alpha}\left(\right.$ ACC $\left._{\alpha}\right)$. The expression of SREBP1 has been found to be reduced by short term fasting in chickens and mammals (Horton et al., 1998; Zhang and Hillgartner, 2004).

In chickens, the SREBP1 and SREBP2 genes are located on the 14th macrochromosome and first microchromosome, respectively (Assaf

Abbreviations: 18S rRNA, $18 \mathrm{~S}$ ribosomal RNA; ACC $_{\alpha}$, acetyl coenzyme A carboxylase ${ }_{\alpha}$; FAS, fatty acid synthase; MAE, malic enzyme; siRNA, small interfering RNA; SREBP, sterol regulatory element-binding proteins.

This work was supported partially by Council of Agriculture in Taiwan.

* Corresponding authors. 50, Lane 155, Kee-Long Rd., Sec 3, Taipei 106, Taiwan. Tel.: +8862 87327350; fax: +8862 27324070 .

E-mail address: sding@ntu.edu.tw (S.T. Ding). et al., 2003). The sequence of chicken SREBP1 is very homologous to the SREBP1a in mammals and there is no evidence for a second form. The predicted amino acid sequences of the basic helix-loop-helix-Zip sequence in chicken SREBP1 show about 91\% homology when compared to mammals whereas the catalytic domain exhibits less homology (Zhang and Hillgartner, 2004). Therefore, the function and regulation of the SREBP genes may not be the same in chickens as in mammals.

Although SREBP1 can bind to the predicted SRE sequence in chicken $\mathrm{ACC}_{\alpha}$ (Zhang and Hillgartner, 2004), the direct regulation of the expression of $A C C_{\alpha}$ and other lipogenic genes by SREBP1 has not been demonstrated. Therefore, we designed short interference RNA ( the expression of $\mathrm{ACC}_{\alpha}$ and FAS. We also established real time PCR techniques to analyze the mRNA of these target genes and determined the effect of fasting on the expression of SREBP and several target genes in broiler chickens.

\section{Methods}

\subsection{Fasting and feeding of broilers}

The animal protocol was approved by the Experimental Animal Care and Use Committee at National Taiwan University. Five week old 
broilers (Gallus gallus) (Arbor Acres; $n=16$ ) were purchased from a commercial farm and fed a commercial corn-soy based diet containing $18 \%$ crude protein and $3200 \mathrm{kcal} \mathrm{ME} / \mathrm{kg}$. The diet was fed for two weeks to allow the birds to adapt to their experimental environment. The broilers were randomly divided into two treatment groups (eight birds a group) and moved to $1.8 \mathrm{~m} \times 1.2 \mathrm{~m} \times 1.2 \mathrm{~m}$ pens with sawdust litter. The water was provided for all birds at all time regardless of different feeding treatments. No artificial lighting program was enforced when the natural lighting period was about $13 \mathrm{~h}$ during the experimental period. One group was fasted for $24 \mathrm{~h}$ while the other group was fasted for $24 \mathrm{~h}$ and then refed for $5 \mathrm{~h}$ prior to euthanasia by cervical dislocation. The liver was removed, frozen in liquid $\mathrm{N}_{2}$ and stored at $-70{ }^{\circ} \mathrm{C}$. Total RNA was extracted using a guanidinium-phenol-chloroform method (Chomczynski and Sacchi, 1987). The SREBP1, ACC ${ }_{\alpha}$, FAS, malic enzyme (MAE), stearyl coenzyme A desaturase 1 (SCD1) and $\beta$-actin gene expression was determined by quantitative real time PCR and two of the genes were also measured by Northern blot analysis to confirm the real time PCR data.

\subsection{Preparation and use of siRNA for SREBP1}

To study the relationship between chicken SREBP1 and the expression of $\mathrm{ACC}_{\alpha}$ and FAS in hepatocytes, gene specific siRNA for SREBP1 was synthesized. Target sequences were as follows: siRNA1-1 sense, GGAAGGCCAUCGAGUACAUtt (lower case nucleotides overhang at the 3' end); antisense, AUGUACUCGAUGGCCUUCCtc; siRNA1-2 sense, GGCUAAGCUCAACAAGUCGtt; antisense, CGACUUGUUGAGCUUAGCCtc; siRNA1-3 sense, GGUGAAGCAGGAGAACCCAtt, antisense, UGGGUUCUCCUGCUUCACCtt. Chicken hepatocarcinoma cells (LMH cells) were cultured in Waymouth's MB 752/1 medium with $10 \%$ fetal bovine serum for cell proliferation. The siRNA were incubated with siPort ${ }^{\mathrm{TM}}$ NeoFX ${ }^{\mathrm{TM}}$ siRNA transfection reagent (Ambion, Austin, TX) for 10 min before transfection. Cells were detached from the plate by Trypsin-EDTA and mixed with the aforementioned transfection mixture at $37{ }^{\circ} \mathrm{C}, 5 \% \mathrm{CO}_{2}$, for $24 \mathrm{~h}$. The cells were harvested after another $24 \mathrm{~h}$ of incubation in Waymouth's MB 752/1 medium. Each

Table 1

Sequences for real time PCR primers.

\begin{tabular}{|c|c|c|c|c|}
\hline Gene $^{a}$ & Primer sequence $\left(5^{\prime} \rightarrow 3^{\prime}\right)$ & $\begin{array}{l}\text { GenBank } \\
\text { accession no. }\end{array}$ & $\begin{array}{l}\text { Product } \\
\text { size (bp) }\end{array}$ & $\begin{array}{l}\text { Annealing } \\
\text { temperature }\left({ }^{\circ} \mathrm{C}\right)\end{array}$ \\
\hline SREBP1 & $\begin{array}{l}\text { Sense: } \\
\text { CTACCGCTCATCCATCAACG } \\
\text { Antisense: } \\
\text { CTGCTTCAGCTTCTGGTTGC }\end{array}$ & AY029924 & 145 & 62 \\
\hline $\mathrm{ACC}_{\alpha}$ & $\begin{array}{l}\text { Sense: } \\
\text { AGTCCTGATTGAGCATGGCA } \\
\text { Antisense: } \\
\text { CTCCAGATGGCGGTAGATTC }\end{array}$ & NM-205505 & 127 & 62 \\
\hline FAS & $\begin{array}{l}\text { Sense: } \\
\text { AAGCAATTCGTCACGGACAG } \\
\text { Antisense: } \\
\text { GGCACCATCAGGACTAAGCA }\end{array}$ & J03860 & 116 & 62 \\
\hline $\begin{array}{l}\text { Malic } \\
\text { enzyme }\end{array}$ & $\begin{array}{l}\text { Sense: } \\
\text { AGTGCCTACCTGTGATGTTG } \\
\text { Antisense: } \\
\text { GGCTTGACCTCTGATTCTCT }\end{array}$ & AF408407 & 101 & 56 \\
\hline SCD1 & $\begin{array}{l}\text { Sense: } \\
\text { AGTGGTGTTGCTGTGCTTCA } \\
\text { Antisense: } \\
\text { CTAAGGTGTAGCGCAGGATG }\end{array}$ & NM_204890 & 107 & 62 \\
\hline$\beta$-actin & $\begin{array}{l}\text { Sense: } \\
\text { GTGATGGACTCTGGTGATGG } \\
\text { Antisense: } \\
\text { TGGTGAAGCTGTAGCCTCTC }\end{array}$ & NM-205518 & 150 & 62 \\
\hline
\end{tabular}

\footnotetext{
a SREBP1 = Sterol response element-binding protein $1 ;$ ACC $_{\alpha}=$ acetyl coenzyme A
} carboxylase alpha; FAS $=$ fatty acid synthase; SCD1 = stearoyl-CoA desaturase 1 .
Table 2

Primer sequences for generating radiolabeled PCR probes.

\begin{tabular}{|c|c|c|c|c|}
\hline Gene $^{a}$ & Primer sequence $\left(5^{\prime} \rightarrow 3^{\prime}\right)$ & Reference & $\begin{array}{l}\text { Product } \\
\text { size (bp) }\end{array}$ & $\begin{array}{l}\text { Annealing } \\
\text { temperature }\left({ }^{\circ} \mathrm{C}\right)\end{array}$ \\
\hline SREBP1 & $\begin{array}{l}\text { Sense: } \\
\text { GAGGAAGGCCATCGAGTACA } \\
\text { Antisense: } \\
\text { GGAAGACAAAGGCACAGAGG }\end{array}$ & $\begin{array}{l}\text { Dridi et al., } \\
2005\end{array}$ & 392 & 58 \\
\hline FAS & $\begin{array}{l}\text { Sense: } \\
\text { ATTGACACAGCCTGCTCCTC } \\
\text { Antisense: } \\
\text { ACGGCTCTCTCTCACATTGG }\end{array}$ & $\begin{array}{l}\text { Yen et al. } \\
\text { (2005) }\end{array}$ & 490 & 58 \\
\hline $18 \mathrm{~S}$ & $\begin{array}{l}\text { Sense: } \\
\text { CTGCCCTATCAACTTTCG } \\
\text { Antisense: } \\
\text { CATTATTCCTAGCTGCGG }\end{array}$ & $\begin{array}{l}\text { Dridi et al. } \\
\text { (2005) }\end{array}$ & 515 & 58 \\
\hline
\end{tabular}

a SREBP1 = Sterol response element-binding protein 1 ; FAS = fatty acid synthase; $18 \mathrm{~S}=18 \mathrm{~S}$ ribosomal RNA.

experiment was repeated for 4 times with cells from different batches. The total RNA was extracted for gene expression analysis by quantitative real time PCR.

\subsection{Transcript analysis}

The mRNA concentrations for SREBP1, ACC, FAS, SCD1 and MAE were quantified by quantitative real time PCR. The primer information for all the genes is listed in Table 1. The total RNA was digested by DNase I to remove genomic DNA contamination and then reverse transcribed with a SuperScript II kit at $42{ }^{\circ} \mathrm{C}$ (Life Technologies, Carlsbad, CA, USA). The real time PCR procedure followed that described by Chin et al. (2007). In short, transcribed cDNA was amplified by PCR and DNA products quantitated using the DyNAmo Flash SYBR Green Kit (Finnzymes, Espoo, Finland) and detected by a DNAEngine OPTICOM ${ }^{\mathrm{TM}} 2$ real time PCR Machine (Bio-Rad, Hercules, CA, USA). The conditions for PCR were denaturation at $94{ }^{\circ} \mathrm{C}$ for $30 \mathrm{~s}$ (5 $\mathrm{min}$ in the first cycle), annealing at an optimized annealing temperature for $30 \mathrm{~s}$, and extension at $72{ }^{\circ} \mathrm{C}$ for $1 \mathrm{~min}$. Each primer pair was examined for its suitability and appropriate annealing temperature in the real time PCR quantitation procedure. Before the primer sets were used in quantitative real time PCR, all the PCR products were sequenced to confirm the accuracy of the reaction. A melting curve was also performed to monitor the specificity of the PCR product for each gene at the end of every PCR reaction. Each sample was measured in duplicate analysis. If the difference between two duplications was greater than $15 \%$, the sample was analyzed again. In this procedure, $\beta$-actin was used as a house-keeping gene to normalize the gene expression data in the quantitative real time PCR. The same procedure has been validated by Chin et al. (2007).

In order to confirm the real time PCR data, we chose to analyze SREBP1 and FAS mRNA concentrations with Northern analysis. Electrophoresis and Northern blotting were performed using $20 \mu \mathrm{g}$ of total RNA from each broiler liver. The concentration of $18 \mathrm{~S}$ ribosomal RNA (18S rRNA), a house-keeping gene, was also quantified for normalization of Northern analysis data (Chen et al., 2006; Ding et al., 2007). The 18S rRNA was chosen in the Northern analysis because it can be a great house-keeping gene and also an indicator of RNA loading accuracy for determining mRNA concentration. Radiolabeled probes synthesized by PCR were used for hybridization. The primer set for each gene is listed in Table 2 and the details of the blotting procedure were described by Chin et al. (2006). The relative mRNA concentration was determined by phosphor-image analysis (Typhoon-9200, General Electric Company, NJ, USA) with ImageQuant software as previously described (Yen et al., 2006). The density value for each sample was normalized to the density value for 18S rRNA in the same sample to correct for extraction, sampling, gel loading, and membrane transfer variation. 
A

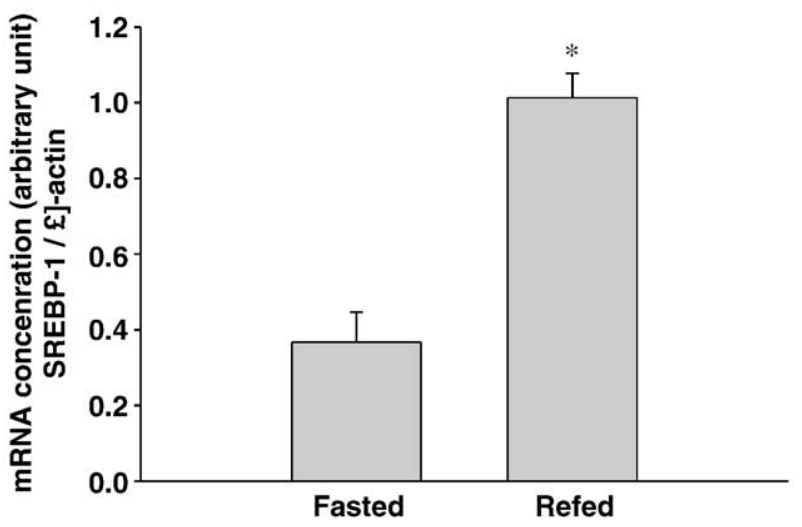

B

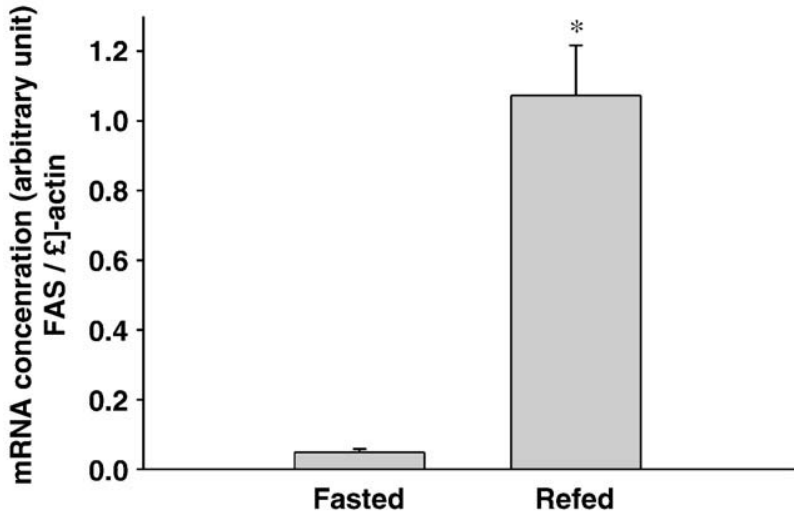

Fig. 1. Effect of fasting ( $24 \mathrm{~h}$ ) and refeeding (for $5 \mathrm{~h}$ ) on SREBP1 and FAS mRNA. Representative real time PCR analysis result of sterol response element-binding protein 1 (SREBP1) mRNA concentration in liver of fasted and refed broilers. (A) Relative hepatic SREBP1 mRNA concentration (SREBP1/ $\beta$-actin) are graphically presented as means \pm SEM $(n=8)$ and $*$ indicates a significant difference between the fasted and refed group $(p<0.001)$. (B) Relative hepatic FAS mRNA concentration (FAS / $\beta$-actin) are graphically presented as means $\pm \operatorname{SEM}(n=8)$.

\subsection{Statistical analysis}

All data from Experiment 1 were analyzed by Student's $t$-test and data from Experiment 2 by ANOVA using the procedures of the SAS

Table 3

The hepatic relative mRNA abundance of hepatic genes in the broilers by real time PCR analysis ${ }^{\mathrm{a}}$.

\begin{tabular}{|c|c|c|c|c|}
\hline & Fasted & Refed & \multirow[t]{2}{*}{$p$-values ${ }^{\mathrm{b}}$} & \multirow[t]{2}{*}{ Ratio $^{c}$} \\
\hline & \multicolumn{2}{|c|}{ Arbitrary unit $^{\mathrm{d}}$} & & \\
\hline SREBP1 & $0.37 \pm 0.08$ & $1.01 \pm 0.06$ & $<0.01$ & 2.7 \\
\hline $\mathrm{ACC}_{<}$ & $0.18 \pm 0.04$ & $1.03 \pm 0.12$ & $<0.01$ & 5.7 \\
\hline FAS & $0.05 \pm 0.01$ & $1.07 \pm 0.14$ & $<0.01$ & 21.4 \\
\hline MAE & $0.06 \pm 0.01$ & $1.05 \pm 0.12$ & $<0.01$ & 17.5 \\
\hline SCD1 & $0.01 \pm 0$ & $1.14 \pm 0.19$ & $<0.01$ & 114.0 \\
\hline SREBP2 & $0.33 \pm 0.04$ & $1.12 \pm 0.17$ & $<0.01$ & 3.4 \\
\hline HMGR & $0.28 \pm 0.04$ & $1.07 \pm 0.15$ & $<0.01$ & 3.8 \\
\hline LDLR & $0.30 \pm 0.05$ & $1.06 \pm 0.12$ & $<0.01$ & 3.5 \\
\hline
\end{tabular}

a ACC $_{\alpha}=$ acetyl coenzyme A carboxylase alpha; FAS = fatty acid synthase; MAE = malic enzyme; HMGR = 3-hydroxy-3-methylglutaryl coenzyme A reductase; LDLR = low density lipoprotein receptor; SCD1 = stearoyl-CoA desaturase 1 ; SREBP1 = Sterol response element-binding protein 1.

b Data were analyzed by Student's $t$-test.

c Ratio = mean of mRNA arbitrary unit in refed group/mean of mRNA arbitrary unit in fasted group.

d Values are ratios of mRNA concentrations to $\beta$-actin mRNA concentration and are expressed as mean \pm SEM $(n=8)$.
SREBP-1

$18 S$
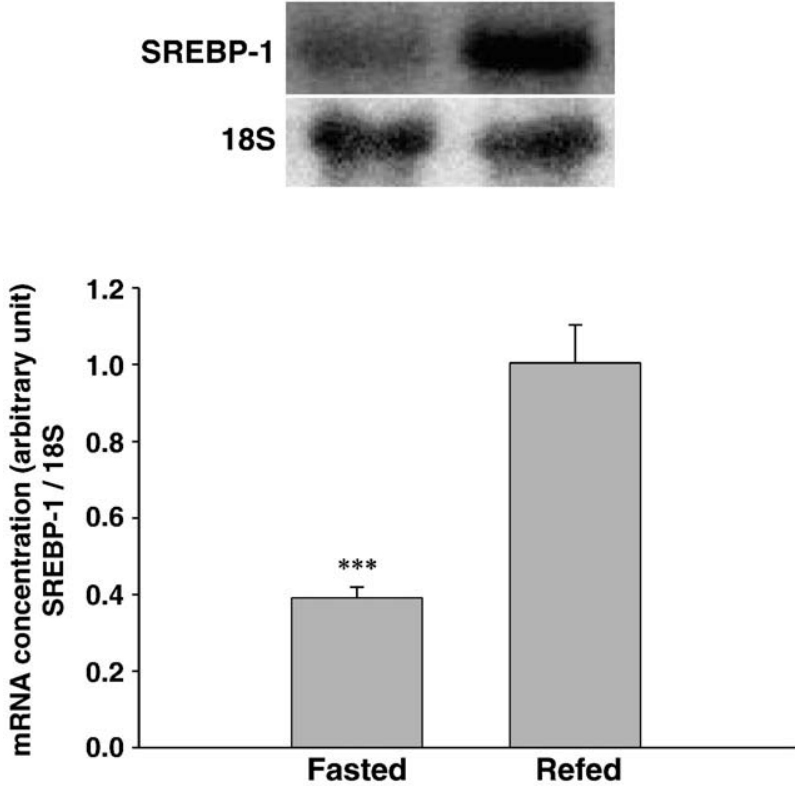

Fig. 2. Effect of fasting ( $24 \mathrm{~h}$ ) and refeeding (for $5 \mathrm{~h}$ ) on SREBP1 mRNA. Representative Northern analysis result of sterol response element-binding protein 1 (SREBP1) mRNA concentration in liver of fasted and refed broilers. Representative Northern analysis result; relative hepatic SREBP1 mRNA concentration (SREBP1/18S rRNA) are graphically presented as means \pm SEM $(n=8)$ and $* * *$ indicates a significant difference between the fasted and refed group $(p<0.001)$.

software (SAS Institute, 2001). The homogeneity was determined to evaluate the requirement of data transformation. Significant differences between treatments were tested by Duncan's New Multiple Test (SAS Institute, 2001). The means and SE for all variables are presented.

FAS

$18 S$
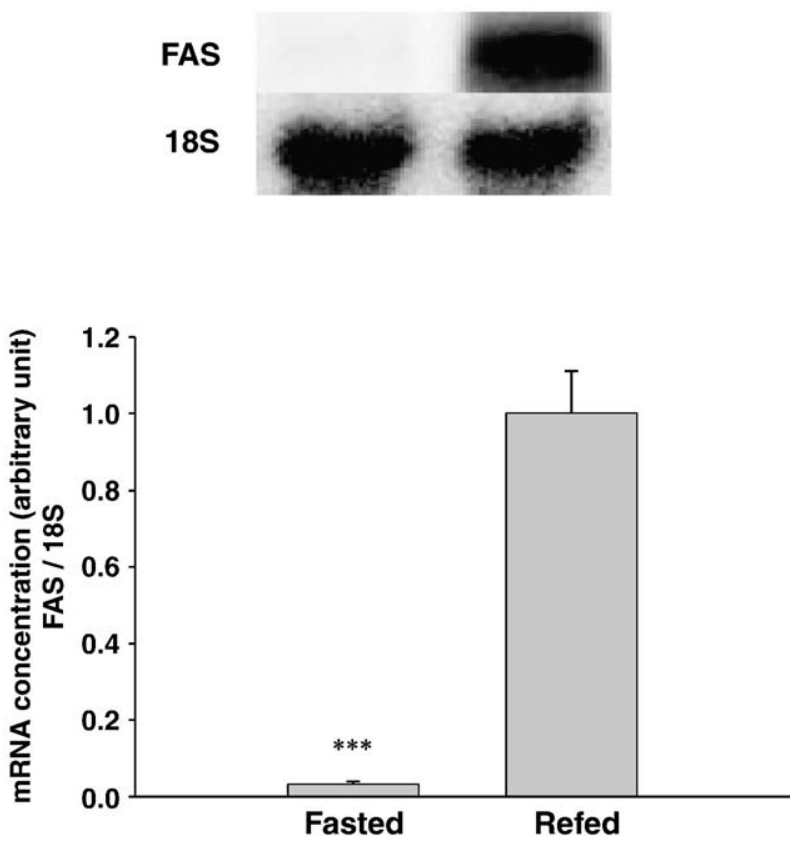

Fig. 3. Effect of fasting ( $24 \mathrm{~h}$ ) and refeeding (for $5 \mathrm{~h}$ ) on FAS mRNA. Representative Northern analysis result of fatty acid synthase (FAS) mRNA concentration in liver of fasted and refed broilers. Representative Northern analysis result; relative hepatic FAS mRNA concentration (FAS/18S) are graphically presented as means $\pm \operatorname{SEM}(n=8)$ and $* * *$ indicates a significant difference between the fasted and refed group $(p<0.001)$. 


\section{Results}

\subsection{Fasting and feeding of broilers}

The lipogenic genes in the liver of the broiler were reduced after a $24 \mathrm{~h}$ fasting (Fig. 1). The SREBP1, MAE, FAS, $\mathrm{ACC}_{\alpha}$, and SCD1 mRNA concentrations were significantly reduced $(p<0.001)$ from 2.7 (SREBP1) to 114-fold (SCD1) when compared with the $5 \mathrm{~h}$ refed group (Table 3). The MAE, FAS, SCD1 mRNA were almost undetectable confirming that lipogenic activity in fasted broilers is very low. The Northern analysis data from SREBP1 and FAS confirmed the real time PCR data (Figs. 2 and 3). For the genes involved in cholesterol biosynthesis [SREBP2, 3-hydroxy-3-methylglutaryl coenzyme A (HMGCoA) reductase, LDLR], the mRNA concentrations were also significantly reduced $(p<0.001)$ in the fasted compared to the refed birds (Table 3).

\subsection{Treatment of SiRNA for SREBP1}

The siRNA1-2 of chicken SREBP1 inhibited the expression of SREBP1 mRNA at about 50\% compared to the control group $(p<0.01)$. The results from the other two siRNA fragments showed no significant effects on reducing the expression of SREBP1 mRNA ( $p>0.05$; Fig. 4). The results indicate that only siRNA1-2 can interfere with the function of SREBP1. The ACC ${ }_{\alpha}$ mRNA level was responsive to the SREBP1 SiRNA, whereas the FAS mRNA was not (Table 4). These results suggest that $\mathrm{ACC}_{\alpha}$ is more sensitive to the SREBP1 siRNA than FAS and the chicken SREBP1 may regulate the expression of $\mathrm{ACC}_{\alpha}$.

\section{Discussion}

\subsection{Effect of fasting and refeeding on lipogenic gene expression}

The current data demonstrated that refeeding for $5 \mathrm{~h}$ after a $24 \mathrm{~h}$ fasting increased the mRNA concentrations of SREBP1, SREBP2, and their assumed target genes. These results also confirm data from studies with 10 to 12 day old Leghorn chicks (Zhang and Hillgartner, 2004) and broiler breeders (Richards et al., 2003). The SREBP1 mRNA was increased approximately twofold while the mature SREBP1 protein was increased approximately thirteenfold (Zhang and Hillgartner, 2004). This suggests that nutrient deprivation can block the expression

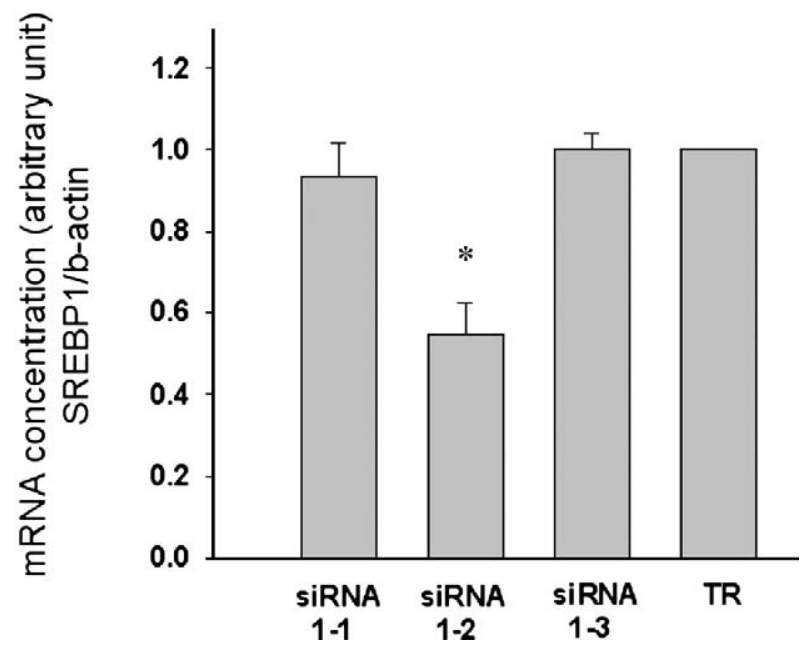

Fig. 4. Effect of siRNA treatment on SREBP1 mRNA concentration. The LMH cells were treated with one of three siRNA $(1-1,1-2,1-3)$ for SREBP1 (sterol response elementbinding protein 1) and the SREBP1 mRNA concentration was quantified by real time PCR. Relative SREBP1 mRNA concentration (SREBP1/ $\beta$-actin) are graphically presented as means \pm SEM $(n=4)$ and $*$ indicates a significant difference between siRNA group and TR group $(p<0.01)$. TR: transfection reagent (without siRNA).
Table 4

The relative mRNA abundance of lipogenic genes in LMH cell treated with siRNA1-2 for SREBP1 $1^{\mathrm{a}}$.

\begin{tabular}{llll}
\hline & SiRNA1-2 & TR & \\
\cline { 2 - 3 } & Arbitrary unit ${ }^{\mathrm{C}}$ & \\
\hline ACC $_{\alpha}$ & $0.80 \pm 0.08$ & $1.08 \pm 0.05$ & $<0.05$ \\
FAS & $1.05 \pm 0.29$ & $0.98 \pm 0.10$ & $>0.05$ \\
\hline
\end{tabular}

SREBP1 = Sterol response element-binding protein $1 ; \mathrm{ACC}_{\alpha}=$ acetyl coenzyme $\mathrm{A}$ carboxylase alpha; FAS $=$ fatty acid synthase; TR $=$ transfection reagent (without SiRNA).

b Data were analyzed by Student's $t$-test.

c Values are ratios of mRNA concentrations to $\beta$-actin mRNA concentration and are expressed as mean $\pm \operatorname{SEM}(n=4)$.

of lipogenic transcription factor SREBP1 in the chicken. A similar observation was reported in mice by Horton et al. (1998). This type of an inhibitory effect on a transcription factor may reduce the expression of its target genes. In the current study, MAE mRNA was increased approximately 17-fold after refeeding which confirms data from young ducks (Goldman et al., 1985). Hillgartner et al. (1996) observed that the expression of hepatic $\mathrm{ACC}_{<}$mRNA was increased by refeeding approximately 6 -fold and this was due to an increase in gene transcription. Therefore, the current observation of increased $\mathrm{ACC}_{<}$and MAE mRNA after refeeding may result from transcriptional regulation. After a $24 \mathrm{~h}$ fasting, the expression levels of FAS and SCD1 mRNA were almost undetectable and refeeding increased their expression dramatically which confirmed data from several groups (Donaldson, 1990; Legrand et al., 1994; Dridi et al., 2005). Richards et al. (2003) found that feed restricted breeder chickens expressed much less hepatic SCD1 when compared with control fed ad libitum. The increased expression of $\mathrm{ACC}_{<}$and FAS will increase the capacity for fatty acid synthesis whereas an increase in SCD1 will increase the synthesis of oleic acid and further stimulate the synthesis of triacylglycerol upon refeeding.

The current study found that refeeding increased the expression of SREBP-2 mRNA which was similar to what was found in mice by Horton et al. (1998) but different from the data of Zhang and Hillgartner (2004) who found that refeeding did not affect the expression of SREBP2 in Leghorn chicks. Similar to Sato et al. (2003), the current study found that refeeding increased the expression of HMG-CoA reductase mRNA concentration in the liver of chickens. The LDLR mRNA was also reduced by the fasting treatment in broilers which is also similar to what was reported in mice (Shimano et al., 1988). Taken collectively, the data show that at the molecular level, fasting reduces the expression of hepatic genes associated with lipogenesis and cholesterol biosynthesis in broiler chickens and refeeding reverses this inhibition.

Similar to chickens, the expression of lipogenesis-related genes, ie., SREBP1c, FAS, ACC and LPL in the liver and adipose tissues was decreased by fasting and increased by refeeding in mammals (Horton et al., 1998; Zhang and Hillgartner, 2004; Palou et al., 2008, in press). Using a transgenic model, Takeuchi et al. (2007) found that expression of hepatic and adipose SREBP1c promoter transgene was increased by refeeding in a similar manner to those of endogenous SREBP-1c mRNA. Because the SREBP1c is the key transcription factor that regulates lipogenic genes (Shimano et al., 1999), the essentially identical regulation patterns of nutritional status on this gene in mammals and avian species indicating that these lipogenic genes are regulated by nutritional status similarly in these species.

\subsection{Effect of siRNA treatment on SREBP1 and FAS mRNA concentration}

The siRNA1-2 effectively reduced SREBP-1 mRNA concentration which suggests that it can create the RNA interference effect on the SREBP1 gene resulting in hydrolysis of the SREBP1 mRNA. The $\mathrm{ACC}_{\alpha}$ mRNA concentration was also reduced by SREBP-1 siRNA, suggesting that in the hepatocarcinoma cells, the reduction of SREBP- 1 mRNA can 
decrease SREBP1 protein which would then reduce the expression of the $\mathrm{ACC}_{\alpha}$ mRNA. Yin et al. (2002) found that 3,5,3'-triidothyronine (T3) increased the expression of $\mathrm{ACC}_{\alpha}$ because $\mathrm{ACC}_{\alpha}$ has a T3 response element (TRE) and a SRE response element in its promoter region. The SREBP1 binds along with T3 to increase the T3 function in stimulating $\mathrm{ACC}_{\alpha}$ expression in embryonic chicken liver. Zhang et al. (2003) also suggested that both cAMP and medium chain fatty acids can reduce the expression of $A_{C C}$ through inhibiting the maturation of SREBP1. Zhang and Hillgartner (2004) reported that in a fed condition, the nuclear form of the SREBP1 protein will be increased and bind to the SRE on the $A C C$ promoter, suggesting that the SREBP1 in the chicken can affect the expression of $\mathrm{ACC}_{\alpha}$. The promoter sequence of chicken FAS (GenBank accession no. X77339) has a SRE-like sequence, GTCAGCCCAT (Magana et al., 2000). However, in the current study, the FAS mRNA was not affected by the reduction in SREBP-1 mRNA caused by the siRNA treatment. Whether this resulted from a less active SRE-like sequence in the SREBP1 promoter region or the siRNA inhibition of SREBP1 was not effective enough in inhibiting gene expression requires further study.

\subsection{Conclusion}

In the current study, we have shown that the lipogenic and cholesterol biosynthesis genes are inhibited by fasting and the reduction of SREBP1 and SREBP2 may have roles in regulating these genes. We also demonstrated through an RNA interference study that SREBP1 has the ability to regulate the expression of $\mathrm{ACC}_{\alpha}$ but has no effect on FAS. This study has helped us to have a greater understanding of the function of SREBP1 and the physiology of the broiler chickens.

\section{Acknowledgements}

The authors thank Michael Lilburn and Harry Mersmann for their editorial inputs.

\section{References}

Assaf, S., Hazard, D., Pitel, F., Morisson, M., Alizadeh, M., Gondret, F., Diot, C., Vignal, A Douaire, M., Lagarrigue, S., 2003. Cloning of cDNA encoding the nuclear form of chicken sterol response element binding protein-2 (SREBP-2), chromosomal localization, and tissue expression of chicken SREBP-1 and -2 genes. Poult. Sci. 82, 54-61.

Chen, C.H., Lin, E.C., Cheng, W.T.K., Sun, H.S., Mersmann, H.J., Ding, S.T., 2006. Abundantly expressed genes in pig adipose tissue: an expressed sequence tag approach. J. Anim. Sci. 84, 2673-2683.

Chin, H.J., Shen, T.F., Su, H.P., Ding, S.T., 2006. Schizochytrium limacinum SR-21 as source of docosahexaenoic acid: optimal growth and use as a dietary supplement for laying hens. Aust. J. Agric. Resour. 57, 13-20.

Chin, H.J., Ko, Y.H., Shen, T.F., Ding, S.T., 2007. The effect of dietary docosahexaenoic acid on the expression of lipogenic genes in broilers. Aust. J. Agric. Resour. 58, 153-159.

Chomczynski, P., Sacchi, N., 1987. Single-step method of RNA isolation by acid guanidinium thiocyanate-phenol-chloroform extraction. Anal. Biochem. 162, 156-159.

Ding, S.T., Yen, C.F., Wang, P.H., Lin, H.W., Hsu, J.C., Shen, T.F., 2007. The differential expression of hepatic genes between pre-laying and laying geese. Poult. Sci. 86 1206-1212.

Donaldson, W.E., 1990. Lipid metabolism in liver of chicks: response to feeding. Poult. Sci. 69, 1183-1187.

Dridi, S., Buyse, J., Decuypere, E., Taouis, M., 2005. Potential role of leptin in increase of fatty acid synthase gene expression in chicken liver. Domest. Anim. Endocrinol. $29,646-660$.
Goldman, M.J., Back, D.W., Goodridge, A.G., 1985. Nutritional regulation of the synthesis and degradation of malic enzyme messenger RNA in duck liver. J. Biol. Chem. 260, 4404-4408.

Hillgartner, F.B., Charron, T., Chesnut, K.A., 1996. Alterations in nutritional status regulate acetyl-CoA carboxylase expression in avian liver by a transcriptional mechanism. Biochem. J. 319 (Pt 1), 263-268.

Horton, J.D., Bashmakov, Y., Shimomura, I., Shimano, H., 1998. Regulation of sterol regulatory element binding proteins in livers of fasted and refed mice. Proc. Natl. Acad. Sci. U. S. A. 95, 5987-5992.

Hua, X., Yokoyama, C., Wu, J., Briggs, M.R., Brown, M.S., Goldstein, J.L., Wang, X., 1993. SREBP-2, a second basic-helix-loop-helix-leucine zipper protein that stimulates transcription by binding to a sterol regulatory element. Proc. Natl. Acad. Sci. U. S. A. 90, 11603-11607.

Hua, X., Wu, J., Goldstein, J.L., Brown, M.S., Hobbs, H.H., 1995. Structure of the human gene encoding sterol regulatory element binding protein-1 (SREBP) and localization of SREBP1 and SREBP2 to chromosomes 17p11.2 and 22q13. Genomics 25, 667-673.

Legrand, P., Catheline, D., Hannetel, J.M., Lemarchal, P., 1994. Stearoyl-CoA desaturase activity in primary culture of chicken hepatocytes. Influence of insulin, glucocorticoid, fatty acids and cordycepin. Int. J. Biochem. 26, 777-785.

Magana, M.M., Koo, S.H., Towle, H.C., Osborne, T.F., 2000. Different sterol regulatory element-binding protein-1 isoforms utilize distinct co-regulatory factors to activate the promoter for fatty acid synthase. J. Biol. Chem. 275, 4726-4733.

Palou, M., Priego, T., Sánchez, J., Villegas, E., Rodríguez, A.M., Palou, A., Picó, C., 2008. Sequential changes in the expression of genes involved in lipid metabolism in adipose tissue and liver in response to fasting. Pflugers Arch. 456, 825-836.

Palou, M., Sánchez, J., Priego, T., Rodríguez, A.M., Picó, C., Palou, A., in press. Regional differences in the expression of genes involved in lipid metabolism in adipose tissue in response to short- and medium-term fasting and refeeding. J. Nutr. Biochem. doi:10.1016/j.jnutbio.2008.10.001 (Electronic publication ahead of print).

Richards, M.P., Poch, S.M., Coon, C.N., Rosebrough, R.W., Ashwell, C.M., McMurtry, J.P., 2003. Feed restriction significantly alters lipogenic gene expression in broiler breeder chickens. J. Nutr. 133, 707-715.

SAS Insttitute, 2001. SAS User's Guide: Statistics. SAS Institute, Inc., Raleigh. NC.

Sato, K., Ohuchi, A., Sook, S.H., Toyomizu, M., Akiba, Y., 2003. Changes in mRNA expression of 3-hydroxy-3-methylglutaryl coenzyme a reductase and cholesterol 7 alpha-hydroxylase in chickens. Biochim. Biophys. Acta 1630, 96-102.

Shimano, H., 2001. Sterol regulatory element-binding proteins (SREBPs): transcriptional regulators of lipid synthetic genes. Prog. Lipid Res. 40, 439-452.

Shimano, H., Aburatani, H., Mori, N., Ishibashi, S., Gotohda, T., Mokuno, H., Kawakami, M., Akanuma, Y., Takaku, F., Murase, T., Yamada, N., 1988. Down-regulation of hepatic LDL receptor protein and messenger RNA in fasted rabbits. J. Biochem. (Tokyo) 104, 712-716.

Shimano, H., Yahagi, N., Amemiya-Kudo, M., Hasty, A.H., Osuga, J., Tamura, Y., Shionoiri, F., Iizuka, Y., Ohashi, K., Harada, K., Gotoda, T., Ishibashi, S., Yamada, N., 1999. Sterol regulatory element-binding protein-1 as a key transcription factor for nutritional induction of lipogenic enzyme genes. J. Biol. Chem. 274, 35832-35839.

Takeuchi, Y., Yahagi, N., Nakagawa, Y., Matsuzaka, T., Shimizu, R., Sekiya, M., Iizuka, Y., Ohashi, K., Gotoda, T., Yamamoto, M., Nagai, R., Kadowaki, T., Yamada, N., Osuga, J., Shimano, H., 2007. In vivo promoter analysis on refeeding response of hepatic sterol regulatory element-binding protein-1c expression. Biochem. Biophys. Res. Commun. 363, 329-335.

Yen, C.F., Jiang, Y.N., Shen, T.F., Wong, I.M., Chen, C.C., Chen, K.C., Chang, W.C., Tsao, Y.K., Ding, S.T., 2005. Cloning and expression of the genes associated with lipid metabolism in Tsaiya ducks. Poult. Sci. 84, 67-74.

Yen, C.F., Lin, H.W., Hsu, J.C., Lin, N.C., Shen, T.F., Ding, S.T., 2006. The expression of pituitary gland genes in laying geese. Poult. Sci. 85, 2265-2269.

Yin, L., Zhang, Y., Hillgartner, F.B., 2002. Sterol regulatory element-binding protein-1 interacts with the nuclear thyroid hormone receptor to enhance acetyl-CoA carboxylase-alpha transcription in hepatocytes. J. Biol. Chem. 277, 19554-19565.

Yokoyama, C., Wang, X., Briggs, M.R., Admon, A., Wu, J., Hua, X., Goldstein, J.L., Brown, M.S. 1993. SREBP-1, a basic-helix-loop-helix-leucine zipper protein that controls transcription of the low density lipoprotein receptor gene. Cell 75, 187-197.

Zhang, Y., Yin, L., Hillgartner, F.B., 2003. SREBP-1 integrates the actions of thyroid hormone, insulin, cAMP, and medium-chain fatty acids on $\mathrm{ACC}_{\alpha}$ transcription in hepatocytes. J. Lipid Res. 44, 356-368.

Zhang, Y., Hillgartner, F.B., 2004. Starvation and feeding a high-carbohydrate, low-fat diet regulate the expression sterol regulatory element-binding protein-1 in chickens. J. Nutr. 134, 2205-2210. 